lems of motion and respiration peculiar to a dense and not especially well-oxygenated medium. Here, too, are chapters dealing with that fascinating, multi-purpose organ, the swimbladder, and that equally fascinating but still somewhat mysterious 'seventh sense', the lateral line sensory system. Sound production, hearing, sight, electrogenesis and luminescence are all dealt with in broad but satisfactory detail. Although these different subjects are perforce considered separately, never once is the reader left with the feeling that they are being viewed in isolation. The first section concludes with three ohapters treating of the ways in which the lives of fishes are conducted on a broader scale. In these chapters, above all, we see the functional integration of the various anatomical, physiological and sensory systems described in earlier sections. Shoaling, migration, courtship, commensalism, mimicry and coloration are all given particular attention, and woven into the persistent theme, devices for survival.

The second section of the book deals with the many aspects of reproductive biology, and the early lifehistories of marine and freshwater fishes. Since less is known about these phases in fishes, it is a relatively short section, but none the less it gives a good coverage of what is known. Again the emphasis is on life and the means of ensuring it, this time more on the strategic than the tactical level.

Finally, the geographical and large-scale ecological bøckground to fish life is described in three chapters covering the deep oceans, the shallow seas, and the freshwater habitats. This is no mere description of the stage and backdrops, for, quite rightly, the actors intrude to demonstrate how they have coped with and often capitalized the vagaries of their world.

Naturally, specialist ichthyologists will feel that some aspects of fish life have received too little attention from the author. Personally, I would have liked to see more space given to the freshwater fishes of Africa and South America, since in many respects these species provide synoptic microcosms of the problems (and their solutions) covered in the book. But such complaints would be churlish. Specialists will also find some orrors of fact, and omissions of work which they consider important, but these are infrequent.

No one can fail to profit from this remarkably lucid, integrated and, above all, biological account of the largest and ecologically most complex group of living vertebrates.

P. H. GREENWOOD

\section{REGENERATION AND RELATED SUBJECTS}

Regeneration in Animals and Related Problems

Edited by V. Kiortsis and H. A. L. Trampusch. (An International Symposium sponsored by NATO'S Division of Scientific Affairs and held at Athens, Greece, April 1964.) Pp. xxiv + 568. (Amsterdam: North-Holland Publishing Company, 1965.) $120 s$.

TCHE subject of regeneration naturally finds a place in most text-books of embryology which usually contain an account of the phenomenon itself and a brief survey of significant experiments in the field. For the interested student such accounts are altogether too brief and will lead him to the standard larger texts on the subject. Unfortunately, these can be comfortably counted on the fingers of one hand and constitute little more than a weekend's reading. The Lagonissi conference on "Regeneration in Animals and Related Problems" has provided the opportunity to create a useful addition to the literature on regeneration.

It is perhaps questionable whether the proceedings of any conference can be welded into a readable whole. Invariably the contributions will be uneven in length, diverse in style and unequal in their scientific merit.
That Regeneration in Animals and Related Problems, containing as it does more than forty contributions, has much of the unity of a general text says much for the skill of the organizers of the conference and the care with which the book has been edited. English readers should be warned that about one in four of the articles is in French.

Of the three sections into which the book is divided, the general section is the most disappointing. This rests more in the placing of the articles than in their content. Herland-Moeve's article on asexual reproduction might well have been placed in the invertebrate section, and it would have been convenient for the reader to have had the notable contribution by $\mathbf{M}$. Singer on nervous control of amphibian limb regeneration alongside that by $\mathrm{C}$. $\mathbf{S}$. Thornton on the influence of wound skin on blastema cell aggregation, which is some 300 pages farther on. Of the two major sections the one on invertebrates is more uniform in its subject matter and slightly more scholarly in its presentation. Here, indeed, is a happy mixture of general reviews and original research papers. Less satisfactory, possibly because the subject matter did not lend itself to a tidy classification, is the section on vertebrates and related problems. One or two articles here seem to be rather short for a book of this kind and do not seem to add much to the understanding of the larger and more exciting problems of regeneration. However, many of the major aspects of limb regeneration in amphibians are dealt with and there are, in addition, excellent articles on such apparently diverse topics as the repair of skin wounds in mammals (D. W. James), compensatory renal hyperplasia (R. J. Goss) and the relation between regeneration and tumour growth (F. Seilernaspang and K. Kratochwil).

Apart from a passing reference to the trials of Prometheus, the influence of Athens appears in the use of the words "Antiphon" and "Colophon" to head introductory and concluding sections by A. E. Needham. Nonmusical readers may be puzzled but they will not be disappointed if they read on. "Antiphon" is a good guide to the contents of the book for the intending purchaser. "Colophon" puts in a plea for regeneration as a discipline in its own right. This is a somewhat sad note on which to end. The study of regeneration has so much to offer biologists in general that one must hope that articles on the subject will long continue to be available to a wide audience, not only by the publication of proceedings of conferences devoted to regeneration, but also in biological journals covering a wider range of subjects.

As the conference was sponsored by the Division of Scientific Affairs of the North Atlantic Treaty Organiza. tion, the absence of contributions from biologists of the U.S.S.R. and other countries outside the Organization is understandable; it is nevertheless regrettable in a symposium claimed to be international. F. S. BILLETT

\section{QUATERNARY STUDIES IN THE UNITED STATES}

\section{The Quaternary of the United States}

Edited by H. E. Wright, Jr., and David G. Frey. (A Review Volume for the VII Congress of the International Association for Quaternary Resoarch.) Pp. $x+922$. (Princeton, N.J. : Princeton University Press; London: Oxford University Press, 1965.) 200s, net.

TTHE adjective 'monumental' is often undeserved, but

The Quaternary of the United States merits it on several counts-whether it be for its 932 pages of large quarto, its 55 authoritative chapters, or the feat of its two editors in assembling together the work of eighty-eight authors in time to have this volume ready for the Seventh Congress of the International Association for Quaternary Research in Colorado in September 1965. 